Univerzitet u Beogradu
Poljoprivredni fakultet
Institut za poljoprivrednu tehniku
Naučni časopis
POLJOPRIVREDNA TEHNIKA
Godina XLVI
Broj 4., 2021.
Strane: $30-40$

UDK: 631.1:621.158.

\title{
DETERMINANTS OF MOBILE PHONES USAGE FOR AGRICULTURAL PURPOSES AMONG ARABLE CROP FARMERS IN IWO ZONE OF OSUN STATE, NIGERIA
}

\author{
Francis Ajayi ${ }^{1}$, Khadijat Olanrewaju, ${ }^{1}$ Olaide Akintunde ${ }^{2 *}$, \\ Olubunmi Bamiwuye ${ }^{1}$, Timothy Agboola ${ }^{2}$ \\ ${ }^{1}$ Department of Agricultural Extension and Rural Development, \\ Osun State University, Osogbo, Nigeria \\ ${ }^{2}$ Department of Agricultural Economics and Agribusiness Management, \\ Osun State University, Osogbo, Nigeria
}

\begin{abstract}
This study examined the socio-economic factors underlining arable crop famers' use of mobile phones for agricultural-related purposes in Iwo Agricultural Development Program (ADP) Zone of Osun State. Multistage sampling procedure was used to select 150 arable crop farmers from whom primary data were collected with structured interview schedule. Data obtained was analyzed using descriptive statistics and ordinary least square regression analysis. Findings from this study revealed that most frequently used applications include voice call $(99.3 \%)$, calendar $(96.7 \%)$, calculator $(96 \%)$ and torch light $(95.3 \%)$. Most of the farmers strongly consented that mobile phones facilitated timely access to needed services $(\bar{X}=4.74)$, eased production decision making $(\bar{X}=4.54)$, enhanced increased income and profit $(\bar{X}=4.50)$ and accessing personalized information about new farming techniques $(\bar{X}=4.44)$. Major constraints identified for limiting the usage of phones for agricultural purposes were poor internet access $(\bar{X}=3.73)$, inadequate electricity to charge the mobile phone $(\bar{X}=3.55)$, poor network access $(\bar{X}=3.54)$ and high charges on services $(\bar{X}=3.41)$. Gender $(\beta=4.337 ; \mathrm{P}<.01)$, level of education $(\beta=16.358 ; \mathrm{P}<.01)$, years of farming $(\beta=0.513 ; \mathrm{P}<.05)$, information sources $(\beta=0.645 ; \mathrm{P}<.01)$ all jointly had positive influence on farmers' use of mobile phones for agricultural information. It was recommended that higher capacity of female and arable crop farmers with lower level of education should be energized to utilize their mobile phones for enhancing their production activities.
\end{abstract}

Keywords: Determinants, mobile, communication, agricultural information, farming

*Corresponding Author: olaide.akintunde@uniosun.edu.ng 


\section{INTRODUCTION}

Information and Communication Technologies (ICT) particularly the use of mobile phones have immensely penetrated every field of life like education, business, commerce, and agriculture [1]. Mobile phone-based communication has rapidly grown in the recent past and became the most used communication tool among all ICTs of the current age. Recent statistics showed that 62.9 percent of the global population already owns a mobile phone with 4.68 billion users on the planet [2]. As such, mobile phones now represent one of the most exciting forms of ICTs particularly in the context of developing nations. The use has opportune speeding up ways in which people get, exchange, and or manipulate information. Specifically, [3] posited that mobile phones have enabled farmers to focus and extract useful and up-to-date information from social and business networks. However, the exploration of other features is still largely limited among rural dwellers, where in the use for making voice calls remains the principal function owing to widespread rural illiteracy and the fact that the calling price system is believed to give more value for money than other features [4], [5].

The exact number of mobile phone users in Nigeria is hard to pin down, currently; estimates from different sources put the number of smartphone users in Nigeria at roughly 25-40 million and its forecasted to grow to more than 140 million by 2025 [2]. There is evidence that rural incomes have been increasing with the use of ICTs to access information [6]. However, there are challenges in making ICT platforms available to a large number of the rural population who are engaged in agriculture and these have to be tackled through public policy in the context of rural development and incentives for investments in rural areas [7]. As such, there is no solely accepted model which is the most effective in access of agricultural information. Fortunately Africa is witnessing a phenomenal increase in mobile phone acquisitions and when they are combined with other ICT platforms like radio the impact on agriculture can be very high [7]. While access to various mobile networks is increasing, it is not yet certain how rural farmers' agricultural activities are aided with mobile phones usage. More so, there is dearth of empirical evidence on the possible effects of the variations in their socio-economic attributes on the usage of the applications for their agricultural activities. In view of these, this study aimed at evaluating the influence of socio-economic factors on arable crop farmers' use of mobile phones in Iwo Agricultural Development Project (ADP) Zone of Osun State. The specific objectives of the study were to

I determine farmers level of usage of mobile phone applications in their agricultural activities,

II examine the benefits derived by farmers from the usage of phone applications for their agricultural activities,

III analyze the socio-economic factors influencing arable crop farmers' use of mobile phones for agricultural information, and

IV assess the constraints facing farmers on use of their mobile phones for agricultural purposes. 


\section{MATERIAL AND METHODS}

Study Area: This study was carried out in Iwo zone of Osun State, Nigeria. The area is one of the three (3) Agricultural Development Project (ADP) zones namely, Osogbo, Iwo and Ife/ Ijesha in the state. Iwo zone covers an area of $245 \mathrm{~km}^{2}$ and has a population of 191,348 people (National Population Commision (NPC), 2006). There are seven Local Government Areas (LGAs) in the zone namely; Iwo, Irewole, Ejigbo, Ayedire, Ayedaade, Isokan and Ola-Oluwa. The people are primarily of Yoruba descent and their major economic activity revolves round agriculture

Source and type of data: Primary data were used for this study. The primary data were obtained with the aid of well-structured questionnaire and unstructured interview. The questionnaire was structured to capture data on socio-economic variables, farmers' use of mobile phone applications in agricultural activities, information on phone applications used in agricultural activities, agricultural benefit of using mobile phone applications, and the constraints that hinder the use of mobile phones by the farmers in the study area.

Sampling techniques and data collection: Multi-stage sampling procedure was used in selecting farmers for this study. The first stage involved purposive selection of three (3) Local Government Areas (LGAs) with highest record of arable crop production from ADP office. Thereafter, five (5) communities were randomly selected from each of the LGAs to make fifteen (15) communities. An average of ten (10) respondents was chosen randomly from each of the fifteen (15) communities to make a total of one hundred and fifty (150) arable crop farmers sampled for the study.

Analytical techniques and models: The study employed analytical tools based on the stated objectives. They include descriptive statistics, inferential statistics, and ordinary least square regression. The descriptive statistics tools used were mean, standard deviation, frequency counts and percentages which were applied to describe socioeconomic characteristics of the farmers. Two-sample t-test as an dinferential statistics tools was used to test the stated hypothesis while ordinary least squares multiple regression model was applied to establish the factors influencing arable crop farmers' use of mobile phones for agricultural information.

Ordinary least squares multiple regression model: The perceived effect of poverty and their determinants were fitted into four functional forms. These models were explicitly specified as follows;

Linear function:

$Y=f\left(b_{0}+b_{1} x_{1}+b_{2} x_{2}+b_{3} x_{3}+b_{4} x_{4}+b_{5} x_{5}+b_{6} X_{6}+b_{7} X_{7}+b_{8} x_{8}+e\right)$

Exponential function:

$\operatorname{LnY}=f\left(b_{0}+b_{1} x_{1}+b_{2} x_{2}+b_{3} x_{3}+b_{4} x_{4}+b_{5} x_{5}+b_{6} x_{6}+b_{7} x_{7}+b_{8} x_{8}+e\right)$ 
Semi - $\log$ function:

$\mathrm{Y}=\mathrm{f}\left(\mathrm{b}_{0}+\mathrm{b}_{1} \ln \mathrm{x}_{1}+\mathrm{b}_{2} \ln \mathrm{x}_{2}+\mathrm{b}_{3} \ln \mathrm{x}_{3}+\ldots \ldots+\mathrm{b}_{5} \ln \mathrm{x}_{5}+\mathrm{b}_{6} \ln \mathrm{x}_{6}+\mathrm{b}_{7} \ln \mathrm{x}_{7}+\mathrm{b}_{8} \ln \mathrm{x}_{8}+\mathrm{e}\right)$

Double-log function:

$\operatorname{LnY}=f\left(b_{0}+b_{1} \ln x_{1}+b_{2} \ln x_{2}+b_{3} \ln x_{3}+\ldots \ldots+b_{6} \ln x_{6}+b_{7} \ln x_{7}+b_{8} \ln x_{8}+e\right)$

Where $\mathrm{Y}=$ Total score of phone applications used in agricultural activities.

$\mathrm{X}_{1}=$ Age of the arable crop farmers in years

$\mathrm{X}_{2}=$ Gender (dummy $=1$ if male, $0=$ if otherwise $)$

$\mathrm{X}_{3}=$ Level of education $($ No formal Education $=0$, Primary School attempted $=2$,

Primary School completed $=3$, Secondary School attempted $=4$, secondary School completed $=5$, tertiary School $=6$ )

$\mathrm{X}_{4}=$ Household size from nominal value of member of the household

$\mathrm{X}_{5}=$ Years of residence in years

$\mathrm{X}_{6}=$ Farming experience in years

$\mathrm{X}_{7}=$ Social capital in total scores of participation in social organization

$\mathrm{X}_{8}=$ Information sources measured as total number of sources used in receiving

information on arable crop farming

$b_{1}-b_{8}$ are the co-efficient parameters to be estimated

$\mathrm{e}=$ stochastic error variable

\section{RESULTS AND DISCUSSION}

\section{Socio-Economic Characteristics of Crop Farmers}

Table 1 shows the average age of the respondents as $49.98 \pm 9.577$ years, with majority been male (76.7\%), and mostly married (90.7\%). This distribution indicates that majority of the farmers in the study area were still in their middle ages and can be able to adopt the use of mobile phones easily. with average number of years spent in school more than 6 , by implication these suggested that majority of the farmers in Nigeria may not have passed through a tertiary school education to attain a high qualification, but have an educational background and as such are literate enough to make use of a mobile phone. The table also revealed the farming experience ( 4.72 years \pm 10.213$)$ in years, with household size of 5 . 
Table 1. Socioeconomics characteristics of crop farmers (Source: Field Survey Data, 2020.)

\begin{tabular}{|c|c|c|c|}
\hline Variables & Frequency & Percentage $(\%)$ & Mean \pm SD \\
\hline \multicolumn{4}{|l|}{ Age } \\
\hline $20-39$ & 23 & 15.3 & \\
\hline $40-59$ & 94 & 62.7 & $49.98 \pm 9.577$ \\
\hline $60-79$ & 33 & 22.0 & \\
\hline \multicolumn{4}{|l|}{ Gender } \\
\hline Male & 115 & 76.7 & \\
\hline Female & 35 & 23.4 & \\
\hline \multicolumn{4}{|l|}{ Marital Status } \\
\hline Single & 3 & 2.0 & \\
\hline Married & 136 & 90.7 & \\
\hline Divorced & 5 & 3.3 & \\
\hline Widowed & 6 & 4.0 & \\
\hline \multicolumn{4}{|l|}{ Education Level } \\
\hline No Formal Education & 7 & 4.7 & \\
\hline Primary school & 13 & 8.7 & \\
\hline SSCE/GCE & 58 & 38.6 & \\
\hline Diploma/NCE & 12 & 8.0 & \\
\hline HND/B.Sc. & 53 & 35.3 & \\
\hline M.Sc. & 6 & 4.0 & \\
\hline Ph.D. & 1 & 0.7 & \\
\hline \multicolumn{4}{|c|}{ Farming Experience (years) } \\
\hline $1-10$ & 71 & 47.3 & \\
\hline $11-20$ & 35 & 23.3 & 4.72 years \pm 10.213 \\
\hline $21-30$ & 39 & 26.0 & \\
\hline$>30$ & 5 & 3.3 & \\
\hline \multicolumn{4}{|c|}{ Household Size (persons) } \\
\hline $1-4$ & 75 & 50.0 & \\
\hline $5-8$ & 75 & 50.0 & \\
\hline \multicolumn{4}{|l|}{ Farm size $(\mathrm{Ha})$} \\
\hline $0-4$ & 80 & 53.3 & \\
\hline $5-9$ & 64 & 42.7 & \\
\hline $10-14$ & 4 & 2.7 & 15.27 years \pm 2.652 \\
\hline$>14$ & 2 & 1.3 & \\
\hline \multicolumn{4}{|l|}{ Land Acquisition } \\
\hline Owner & 144 & 96.0 & \\
\hline Leased & 6 & 4.0 & \\
\hline
\end{tabular}


Farmers' uses of mobile phone in agricultural activities

Farmers' uses of mobile phone in agricultural activities are presented in Table 2. The results show that the applications used daily by most farmers phones were that of voice call $(99.3 \%)$, calendar $(96.7 \%)$, calculator $(96 \%)$, torch light $(95.3 \%)$, WhatsApp $(68 \%)$ and Facebook (67\%). These applications were found to be used virtually every day by most of the farmers and as such they could be pin-pointed as the main phone applications frequently employed for facilitating farmers agricultural activities. Substantial use of radio, browsers and camera were also indicated as used daily by $48.7 \%, 33.3 \%$ and $22.8 \%$ of farmers. On the hand, multi-media messaging and other social media applications including $2 \mathrm{go}$, Instagram and twitter were indicated as grossly unused by the farmers. The findings of this study agrees with [8] who discovered that making phone calls ranked highest in the use of phone by the farmers in Nigeria.

Table 2. Distribution of Farmers' uses of mobile phone in agricultural activities

\begin{tabular}{|c|c|c|c|c|c|c|c|}
\hline \multirow[t]{2}{*}{ Ser.No } & \multirow{2}{*}{$\begin{array}{l}\text { Phone Applications } \\
\text { used in agricultural } \\
\text { activities }\end{array}$} & \multicolumn{5}{|c|}{ Frequency of use in agricultural activities } & \multirow[b]{2}{*}{ Rank } \\
\hline & & $\begin{array}{l}\text { Daily } \\
(\%)\end{array}$ & $\begin{array}{l}\text { Weekly } \\
(\%)\end{array}$ & $\begin{array}{l}\text { Forthrightly } \\
(\%)\end{array}$ & $\begin{array}{l}\text { Monthly } \\
(\%)\end{array}$ & $\begin{array}{l}\text { Not } \\
\text { at all } \\
(\%)\end{array}$ & \\
\hline 1 & $\begin{array}{l}\text { Short Message } \\
\text { Service (SMS) }\end{array}$ & 8 & 3.3 & 0.7 & 34.7 & 53.3 & $10^{\text {th }}$ \\
\hline 2 & Voice call & 99.3 & 0.67 & & & & $1^{\text {st }}$ \\
\hline 3 & $\begin{array}{l}\text { Multi Media } \\
\text { Message (MMS) }\end{array}$ & & & & & 100 & \\
\hline 4 & $\begin{array}{l}\text { Browsing and } \\
\text { Surfing }\end{array}$ & 33.3 & 2 & & & 63.7 & $7^{\text {th }}$ \\
\hline 5 & Radio & 48.7 & 1.3 & 4.7 & 1.3 & 44 & $6^{\text {th }}$ \\
\hline 6 & Voice recording & 18.67 & 1.3 & 0.7 & 4 & 75.3 & $9^{\text {th }}$ \\
\hline 7 & Camera & 22.8 & 9.4 & & 3.4 & 64.4 & $8^{\text {th }}$ \\
\hline 8 & Calendar & 96.7 & 0.7 & & & 2.7 & $2^{\text {nd }}$ \\
\hline 9 & Calculator & 96 & 0.7 & & & 2.7 & $2^{\text {nd }}$ \\
\hline 10 & Torchlight & 95.3 & & 4.7 & & & $3^{\text {rd }}$ \\
\hline 11 & Alarm/reminder & 8.7 & 2 & 0.7 & 16 & 72.7 & $11^{\text {th }}$ \\
\hline 13 & $\begin{array}{l}\text { Google app for } \\
\text { downloading other } \\
\text { apps. }\end{array}$ & 0.7 & 1.3 & & 16 & 82 & $14^{\text {th }}$ \\
\hline 14 & Games & 2 & 0.7 & 1.33 & 4 & 92.6 & $13^{\text {th }}$ \\
\hline 15 & Music & 6 & 1.3 & & 6.7 & 86 & $12^{\text {th }}$ \\
\hline $\begin{array}{l}16 \\
\text { A } \\
\text { B } \\
\text { C } \\
\text { D } \\
\text { E } \\
\text { F } \\
\text { F }\end{array}$ & $\begin{array}{l}\text { Social apps. } \\
\text { WhatsApp } \\
\text { Facebook } \\
\text { Instagram } \\
\text { 2go } \\
\text { Twitter } \\
\text { Telegram }\end{array}$ & $\begin{array}{l}68 \\
67.3 \\
67 . \\
3\end{array}$ & & & & $\begin{array}{l}32 \\
32.7 \\
100 \\
100 \\
100 \\
100 \\
100\end{array}$ & $\begin{array}{l}4^{\text {th }} \\
5^{\text {th }}\end{array}$ \\
\hline 17 & Google map & 0.7 & & & 1.3 & 98 & $15^{\text {th }}$ \\
\hline
\end{tabular}

Source: Field Survey Data, 2020. 


\section{Agricultural benefits of using Mobile Phone applications}

Results in Table 3 shows the farmers' mean ratings of the agricultural benefits of mobile phone usage. The results show that most of the farmers strongly consented that mobile phones facilitated timely access to needed services $(\bar{X}=4.74)$, eased production decision making $(\bar{X}=4.54)$, enhanced increased income and profit $(\bar{X}=4.50)$ and accessing personalized information about new farming techniques $(\bar{X}=4.44)$. These benefits ranked $1^{\text {st }}, 2^{\text {nd }}, 3^{\text {rd }}$ and $4^{\text {th }}$ respectively among the agricultural benefits derived by farmers for using mobile phones. Other benefits include; gaining access to weather forecast information $(\bar{X}=4.38)$, improving farm productivity $(\bar{X}=4.37)$, access to updated price information $(\bar{X}=4.35)$, increasing connectivity with other stakeholders $(\bar{X}=4.35)$, reducing travel hours and costs $(\bar{X}=4.35)$, facilitating local market chains $(\bar{X}=4.34)$, making procurement of agricultural input easy $(\bar{X}=4.31)$, improving supply management $(\bar{X}=4.31)$, enable giving real time feedback of agricultural activities $(\bar{X}=4.31)$, improving management of agricultural resources $(\bar{X}=4.30)$, saves money, energy and time $(\bar{X}=4.11)$.

These results confirmed that farmer's use of phones facilitated their timely access to inputs, market information and enabled better management of their production activities and thereby greater productivity. Undoubtedly, time saving and cost reduction potentials of phones use in farm production logistics are of innumerable importance in agribusiness management. This is because arable crops production is extremely time-sensitive, thus the farmers who use mobile phones would be better off in operating their farm activities and empowered to guard against products perishability and spoilage in the marketing process. Overall, these confirm that attested to the beneficial importance of phones use for agricultural activities and business.

Table 3. Mean scores of farmer's benefits of owning mobile phones in the study area

\begin{tabular}{|c|c|c|c|}
\hline Benefits & Mean $(\overline{\boldsymbol{X}})$ & Standard Deviation (SD) & Rank \\
\hline $\begin{array}{l}\text { Facilitate timely access to needed } \\
\text { es Services }\end{array}$ & 4.74 & 0.44 & $1^{\text {st }}$ \\
\hline $\begin{array}{l}\text { Make production decision making } \\
\text { Easy }\end{array}$ & 4.54 & 0.526 & $2^{\text {nd }}$ \\
\hline $\begin{array}{l}\text { Enhanced increased Income and } \\
\text { profit }\end{array}$ & 4.50 & 0.515 & $3^{\text {rd }}$ \\
\hline $\begin{array}{l}\text { Getting personal Information } \\
\text { about new farming techniques }\end{array}$ & 4.44 & 0.66 & $4^{\text {th }}$ \\
\hline $\begin{array}{l}\text { Gaining access to Weather } \\
\text { Forecast information }\end{array}$ & 4.38 & 0.739 & $5^{\text {th }}$ \\
\hline Improves Farm Productivity & 4.37 & 0.689 & $6^{\text {th }}$ \\
\hline $\begin{array}{l}\text { Gives access to updated } \\
\text { information on market price }\end{array}$ & 4.35 & 0.645 & $7^{\text {th }}$ \\
\hline $\begin{array}{l}\text { Enabling e connectivity with } \\
\text { consumers and Traders }\end{array}$ & 4.35 & 0.533 & $8^{\text {th }}$ \\
\hline Reduce need for travel and Costs & 4.35 & 0.604 & $9^{\text {th }}$ \\
\hline Facilitate Local Market Chains & 4.34 & 0.674 & $10^{\text {th }}$ \\
\hline $\begin{array}{l}\text { Make Procurement of Agricultural } \\
\text { inputs Easy }\end{array}$ & 4.31 & 0.634 & $11^{\text {th }}$ \\
\hline $\begin{array}{l}\text { Enable improved Supply } \\
\text { Management }\end{array}$ & 4.31 & 0.615 & $12^{\text {th }}$ \\
\hline
\end{tabular}




\begin{tabular}{llll}
\hline $\begin{array}{l}\text { Continued Tab.3. } \\
\text { Enable giving real-Time Feedback } \\
\text { on Agricultural Activities }\end{array}$ & 4.31 & 0.677 & $13^{\text {th }}$ \\
$\begin{array}{l}\text { Improve Management of } \\
\begin{array}{l}\text { Agricultural Resources } \\
\text { Save Money, Energy and Time }\end{array}\end{array}$ & 4.3 & 0.621 & $14^{\text {th }}$ \\
use for Entertainment & 4.11 & 0.77 & $15^{\text {th }}$ \\
\hline
\end{tabular}

Source: Field Survey Data, 2020.

Factors influencing arable crop farmers' use of mobile phones for agricultural information

Table 4 presented the result of the regression analysis on the factors influencing arable crop farmers' use of mobile phones for agricultural information. The coefficient of multiple determination $\left(\mathrm{R}^{2}\right)$ shows that $66.0 \%$ of the variation in arable crop farmers' use of mobile phones is been explained by the included independent variables in the model. The coefficient of $\mathrm{R}^{2}$ and $\mathrm{F}$ statistics which is significant at $\mathrm{p}<0.01$ shows that the exponential model is well fitted. The results in Table 5 show that age of the arable crop farmers, gender, level of education, years of farming, and information sources were the factors influencing arable crop farmers' use of mobile phones for agricultural information in the study area.

There is a positive relationship between the coefficient of gender and the arable crop farmers' use of mobile phones for agricultural information and the variable was statistically significant at $1 \%$ level of significance. This result implies that for every unit increase in male, we expect a 4.337 units increase in the use of mobile phones by the arable crop farmers with a predicted score of 4 points higher in males than females. This result reveals that male arable crop farmers make use of their phones for agricultural purposes than the females. This finding is similar to the viewpoint of [9] that confirmed a significant categorical relationship between the gender of respondents and their intention to use mobile phones in agriculture.

The results in Table 5 reveal that level of education has a positive and significant relationship with farmers' use of mobile phones for agricultural information at $p<0.01$ critical level. This indicates that a year increase in the year of tertiary education will increase the arable crop farmers' use of mobile by 16.358 units with a predicted score of 16 points higher in tertiary education than other levels of education. This result is expected as higher level of education tends to enhances farmers' inquisitiveness to explore phone in sourcing information on modern techniques of crop farming and marketing. However, this result contradicts with findings of [8] that posited that educational qualification does not significantly contribute to the prediction of farmers' use of mobile phones for agricultural information in Nigeria.

The coefficient of years of farming experience was positive and statistically significant at 5\% level of significance. This implies that a unit increase in the years of farming experience tends to increase the arable crop farmers' use of mobile by 0.513 units. This result disagrees with the similar study of [8] that confirmed that years of farming experience was not a significant factor determining the farmers' use of mobile phones for agricultural information in Nigeria. 
Sources of receiving information on arable crop farming show a positive relationship with farmers' use of mobile phones for agricultural information and statistically significant at $\mathrm{p}<0.01$ critical level.

It implies that a unit increase in the sources of receiving information on arable crop farming will increase the arable crop farmers' use of mobile phones by 0.645 units. This result reveals that a farmer that has more sources of receiving information on arable crop farming tends to use mobile phone to access information more than the farmer that has few sources of information.

Table 4. Mean scores of constraints that hinder the use of Mobile Phones in the study area

\begin{tabular}{|c|c|c|c|}
\hline Constraints & Mean $(\overline{\boldsymbol{X}})$ & $\begin{array}{l}\text { Standard Deviation } \\
\text { (SD) }\end{array}$ & Rank \\
\hline $\begin{array}{l}\text { Problem in understanding phone } \\
\text { features }\end{array}$ & $2.61 *$ & 0.940 & $7^{\text {th }}$ \\
\hline Limited skill to the use of phone & $3.23 *$ & 0.991 & $5^{\text {th }}$ \\
\hline $\begin{array}{l}\text { Inadequate electricity for charging of } \\
\text { phone }\end{array}$ & $3.55 *$ & 0.764 & $2^{\text {nd }}$ \\
\hline Non-availability of helpline & $2.55^{*}$ & 0.691 & $9^{\text {th }}$ \\
\hline $\begin{array}{l}\text { Inadequate money for phone } \\
\text { recharge/ data purchase }\end{array}$ & 2.43 & 0.572 & $11^{\text {th }}$ \\
\hline High Charges on services & $3.41 *$ & 0.956 & $4^{\text {th }}$ \\
\hline Poor Network connection & $3.54 *$ & 0.841 & $3^{\text {rd }}$ \\
\hline Poor Internet Access & $3.73 *$ & 0.853 & $1^{\mathrm{st}}$ \\
\hline High cost of repair of faulty phone & $2.85 *$ & 0.918 & $6^{\text {th }}$ \\
\hline $\begin{array}{l}\text { Non-availability of Phone repairer in } \\
\text { this vicinity }\end{array}$ & $2.55^{*}$ & 0.765 & $8^{\text {th }}$ \\
\hline accessibility of recharge voucher & 2.46 & 0.765 & $10^{\text {th }}$ \\
\hline Unavailability of phone accessories & 2.11 & 0.608 & $13^{\text {th }}$ \\
\hline $\begin{array}{l}\text { Inability to Read and Write } \\
\text { (Illiteracy) }\end{array}$ & 2.45 & 1.020 & $12^{\text {th }}$ \\
\hline
\end{tabular}

\section{CONCLUSION AND RECOMMENDATION}

This study affirmed arable crop farmer's deployment of mobile phones for facilitating agricultural activities. It was shown that voice call, calendar, calculator torchlight and radio were the most frequently used in the course of agricultural activities. The findings revealed that farmer's use of phones facilitated timely access to inputs, market information and enabled better management of their production activities and thereby greater productivity. Furthermore, socio-economic characteristics including gender, education, farming experience and number of information source explored by the farmers are key determinants of farmer's use of the phones for agricultural purposes. As such, the male farmers were flagged with higher tendency to deploy phones usage for agricultural purpose just as farmers with tertiary education excelled others accordingly. 
Higher farming experience was found to stipulate increased use of phones for enhancing the production processes just as the multiplicity of information sources explored by farmers attracted greater phone usage for the agricultural processes.

The factors influencing arable crop farmers' use of mobile phones for agricultural information in the study area include age of the arable crop farmers, gender, level of education, years of farming, and information sources. In spite of the efficacy of mobile phone use for agribusiness, farmers will always be frustrated and eventually underutilize the technology especially when necessary infrastructure and enabling environment are lacking. Therefore, government and other stakeholders should provide adequate infrastructural facilities, especially electricity also internet providers should make available to farmers low tariff and internet access availability. As such, it was concluded that arable crop farmer's exploration of mobile phones for facilitating their agricultural productivity is substantially underlined by the gender, education level, year of experience as well as number of sources accessed for agricultural information reception. Given this, it was recommended that higher capacity of female and arable crop farmers with lower level of education should be energized to utilize their mobile phones for enhancing their production activities. Also, rural telephone expansion with quality of service is needed in Nigeria by the government and telephone service providers. Also, policy focus should be geared towards low tariff plans for farmers, stable electricity in the rural areas, and training on the use of mobile phone features.

\section{REFERENCES}

[1] Khan, N.A., Qijie, G., Ali, S., Shahbaz, B., Shah, A.A. 2019. Farmers use of mobile phone for accessing agricultural information in Pakistan: a case of Punjab province. Ciencia Rural, Santa Maria, Vol 49 (10), pp. 35-45.

[2] STATISTA, 2019. https://www.statista.com/statistics/501044/number-of-mobile-cellularsubscriptions-in-nigeria/

[3] Overa, R. (2011). Networks distance and trust: telecommunications development and changing trading practices in Ghana. World Development, Vol 34(7), pp.324-335.

[4] Mundi, I. (2011). Kenya Literacy [Retrieved 23rd May, 2015 from http://www.indexmundi.com/kenya/literacy.html]

[5] Ogunniyi, M.D., Ojebuyi, B.R. 2016. Mobile Phone Use for Agribusiness by Farmers in Southwest Nigeria. Journal of Agricultural Extension, Vol 20 (2), pp.172-187

[6] Bertolini, R. 2012. Making Information and Communication Technologies Work for Food Security in Africa: IFPRI 2020 Africa conference brief pp. 11.

[7] Asenso-Okyere, K., Mekonnen, D.A. 2012. The Importance of ICTs in the Provision of Information for Improving Agricultural Productivity and Rural Incomes in Africa: UNDP working paper 2012-2015.

[8] Akinola, A.A. 2017. Influence of socio-economic factors on farmers' use of mobile phones for agricultural information in Nigeria. Library Philosophy and Practice, Vol (1), 1-14.

[9] Lubua, E. W., Kyobe, M. E. 2019. The Influence of Socioeconomic Factors to the Use of Mobile Phones in the Agricultural Sector of Tanzania. The African Journal of Information Systems, Vol 11(4), pp. 352-356.

Available at: https://digitalcommons.kennesaw.edu/ajis/vol11/iss4/2 


\title{
DETERMINANTE KORIŠĆENJA MOBILNIH TELEFONA ZA POLJOPRIVREDNE NAMENE KOD FARMERA U IWO ZONI DRŽAVE OSUN, NIGERIJA
}

\author{
Francis Ajayi ${ }^{1}$, Khadijat Olanrewaju, ${ }^{1}$ Olaide Akintunde ${ }^{2}$, \\ Olubunmi Bamiwuye ${ }^{1}$, Timothy Agboola ${ }^{2}$ \\ ${ }^{I}$ Department of Agricultural Extension and Rural Development, \\ Osun State University, Osogbo, Nigeria \\ ${ }^{2}$ Department of Agricultural Economics and Agribusiness Management, \\ Osun State University, Osogbo, Nigeria
}

Sažetak: Ova studija je ispitala socio-ekonomske faktore koji naglašavaju upotrebu mobilnih telefona kod farmera proizvođača ratarskih kultura za poljoprivredne svrhe u zoni Programa poljoprivrednog razvoja oblasti Iwo (ADP) u državi Osun, Nigerija. Višestepena procedura uzorkovanja je korišćena za odabranih 150 farmera-ratara kod kojih su prikupljeni primarni podaci sa strukturnim rasporedom intervjua. Dobijeni podaci su analizirani korišćenjem deskriptivne statistike i regresione analize najmanjeg kvadrata. Nalazi ove studije su pokazali da najčešće upotrebljene aplikacije uključuju: pozive glasom (99,3\%), kalendar (96,7\%), kalkulator (96\%) i svetlo sa mobilnog telefona $(95,3 \%)$. Većina farmera se jednoglasno složila da su mobilni telefoni olakšali: blagovremeni pristup potrebnim uslugama $(\bar{X}=4.74)$, lakše donošenje odluka o proizvodnji $(\bar{X}=4.54)$, povećali prihod i profit $(\bar{X}=4.50)$, poboljšali pristup personalizovanim informacijama o novitetima poljoprivredne tehnike $(\bar{X}=4.44)$.

Glavna ograničenja identifikovana kod upotrebe mobilnih telefona u poljoprivredi bili su: loš kvalitet pristupa internetu $(\bar{X}=3.73)$, neadekvatna/nepristupačna električna energija za punjenje mobilnog telefona $(\bar{X}=3.55)$, loš pristup mreži $(\bar{X}=3.54)$ i visoka naplata usluga mobilnih operatera $(\bar{X}=3.41)$. Ispitani su i pol farmera $(\beta=4.337 ; \mathrm{P}<.01)$, stepen obrazovanja $(\beta=16.358 ; \mathrm{P}<.01)$, godine bavljenja poljoprivrednom proizvodnjom ili iskustvo $(\beta=0.513 ; \mathrm{P}<.05)$, izvori informacija $(\beta=0.645 ; \mathrm{P}<.01)$.

Svi navedeni parametri su zajedno uticali pozitivno na upotrebu mobilnih telefona za poljoprivredne informacije kod farmera.

Preporuka istraživanja je da se podstakne viši stepen korišćenja mobilnih telefona kod farmera sa nižim stepenom obrazovanja u procesu unapređenja poljoprivrednih aktivnosti.

Ključne reči: Determinante, mobilni, komunikacija, poljoprivredne informacije, poljoprivreda

Prijavljen:

Submitted:

24.05.2021

Ispravljen:

Revised:

01.07.2021.

Prihvaćen:

Accepted:

02.09.2021. 